Srios I

$(1798-1826)$

mins.s.

\title{
XXXIV. On malting
}

\section{John Carr Esq.}

To cite this article: John Carr Esq. (1808) XXXIV. On malting , Philosophical Magazine Series 1, 31:123, 177-187, DOI: $10.1080 / 14786440808563881$

To link to this article: http://dx.doi.org/10.1080/14786440808563881

$$
\text { 册 Published online: } 18 \text { May } 2009 .
$$

6 Submit your article to this journal $\square$

Џ Article views: 2

Q View related articles $\asymp$ 
the gas. I did not remark anv perceptible difference between them; it appeared, however, as if the colour was less weakened with the sulphurous acid gas than with the licuid sulphurous acid.

Besides, this slight difference might perhaps be owing to the greater quantity of colouted liquor employed in the latter experiments, and to the faciliy of observing the effects of the gas, and to that of directing its action at pleasure.

For the present I confire muself to a simple detall of facts, and $I$ have reason to think it correct.

The same experiments repeated with su'phurous acid, obtained either by the mtermedium of charcoal or by that of sugar, furnished simular results.

\section{On Malting. By John Carr, Esq.}

[Continued from p. 102.]

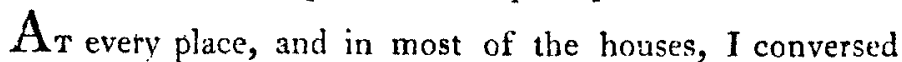
with the common workmen, and endeavoured to collect from them their practice and ideas of malting. Many of them were old and intelligent men, and had worked in malt-houses all their time. They declared, they had never used themselves, or seen others use any water upon the floors; and they all believed it could not be employed there without injury. When asked, why they worked the young floors so cool? they said, to prevent the corn from sweating out the cistern water, and to keep the floors back, (meaning the vegetation.) When interrogated why it was necessary to keep back the vegetation at first? they replied, if it was allowed to go on too quick at first, it would both sweat out the moisture and drive out a long tas (root). And when questioned as to what injury would result frum a long root? their reply was, it would mu the inside of the corn out, and make light malt. These were the artual expressions of many, and the ideas of all ; their opinions of the acrospire were also very similar. Most of them signified that they wished to get it no farther than over the hack of the corn, meaning the thickest part of the barley, and none were de-

Vol. B1. No. 123. Aug. 1808.

M

sirous 
sirous of carrying it more than three-fourths up. All of them maintained that the barley might be perfectly malted beyond the acrospire, and that driving it up to, or beyond the end of the grain would spend the inside, and make the malt less productive.

My enquuiry was not limited to the common workmen, for I endeavoured to select and converse with many of the most intelligent and best informed masters; and I met with several who aftorded much useful information. Some of them had worked many years themselves, and their malt was in the highest repute in the markets; their account of the process of malting was to the following effect: That the cistern water was amply sufficient when the working was properly conducted, for the malting of every variety of barleys. That they had nialted barley's from every kind of light and heavy soils, and from almost every couniry, even as far as Scotland on the one hand, and Devonshire on the other; and they considered it as entirely groundless to imagine that there did any where exist a kind of barley which required watering on the floors more than the Hertfordshire. Their ideas were the contrary; for the more inferior the barley was, the more readily it would spend itself by running out in a quick vegetation; and the less there was of the original substance, the less of it could be spared in the process of malting it; whereas their own large plump corn would, if the thing were necessary, stand watering on the floors beyond any other kind, less bold and abundant in body. Nevertheless, though the fact really was that their own large grain would stand watering better than any other of an inferior quality, they were well convinced, that were they to practise watering, their-malts wonld be light, and much in ferior to those which they now make without watering; and they considered it as a case almost self-evident, that if their own full-sized barleys could be well and even best malted without watering, the malting of all other inferior kinds might be still easier accomplished in the same way.

They were all of opinion, that weight is the best criterion of good malt, when the grain is perfectly malied, and this was now so well known in the market, that weight and tenderness 
derness were the only qualities in estimation there, and their own maits preserved their superior prices entirely from thcse characters. In the working process they knew that both the root and acrospire consumed the substance of the barley, and that the only mode of preserving weight in malt, was by preventing these from proceedirg any farther than was consistent with the malung of the barley; and that this could not be accomplished if the thors were watered, from the too powerful vegetation which it promotes. Some of them had been down in the lower parts of Suffilk, and in other places whcre watering is practised, and had observed there, that the custom of watering resulted from improperly allowing the young floors to heat, in order to forward the private views of the maltsters; and the conzequence was that much more root and a longer acrospire were driven out in these than in the Hertordshire malts, and the former were, on that account, for the most part lighter than the latter, by twenty pounds in four bushels.

I also met with several intelligent commun brewers, who wcre likewise considerable malssters, and who declared, that their experience in brewing had confirmed to them that upwards of half a barrel of wort of equal quality could be drawn from a quarter of unwatered malt more than from malt which had been watered on the floors. They related many other interesting particulars, all directly in favour of ma't made without $u$ atering; and they declared the r opinions, both as brewers and maltsters, wot only to be decidedly in preference of such mals, but also that every variety of barleys might be readily and best malted without any sprinkling upou the for.

In my progress through the country I visited the breweries, and examined the ales and goods in the mash tuns, and more esfecially the grains, which were thin transparent husks, and more perfeety spent than I ever recollect seeing betore The ustrai lengths were three barrels and a half to a quarter of malt, and this I know to be upwards of half a barrel more than the brewers in Manchester draw from their malts, and the ales of the latter I also think inferior.

In the course of my journey I met with only two houses 
where any brown malt was making, and at one of these only two steepings were in operation. At another place a little amber malt was in process, and these were the only porter malts (except the pale) which occurred to notice in the whole enquiry. In truth there cannot prevail a more erroneous opinion than that which the agents of the watering party endeavoured to inculcate, and apparently with much success, in the committee of enquiry into malting, that the Hertfordshire malts are manufactured with an exclusive view to the brewing of porter, and are, on that account, unfit for the brewing of country ales. Very little porter indeed (I found it only at one house) is drunk in any of the places which I visited; and the ales are all brewed from the same pale malts which are sent in such abundance to the Londen market.

The vast mass of pale malt which I saw in operation is perfectly well adapted for the brewing of every species of the best ales that are or can be made in any part of the kingdom; and I bumbly think that its superior weight, price, and quantity of wort drawn from it, all demonstrate that it really is the best and most productive malt made in the kingdom; and sure I am that all its superiority results from the mode of its manufacture.

Much the greater part of this malt is made from barleys purchased in London, and brought thither from various and distant parts of the country. I specially examined the barleys at most of the houses, and found them of all varicties and qualities. Very little regard was paid as to keeping the light and heavy land barleys apart, provided they were nearly of the same size, but small and light conn was separated from the large and stronger grain.

After returning to London from the north, I again set out into Surrey and the country west of London, where I found the practice of watering the corn upon the floors very general. I visited in all about 60 malt houses of this description. At some the steepings were made at every third, and at others every fourth day. From four to six floors were depending at each house, and the steepings were dried off a third part at a time. For the first three days after the barley 
is thrown out of the cistern it is kept sixteen or eighteen inches deep, and in that time sweats very much from the heat which is allowed to accumulate in it, and when the root is quite out it is thrown abroad as a floor. The root runs out straight, and 1 generally found it on the fourth day as long, and in many instances longer, than it was in Hertfordshire on the eighth day. After much of the cistern water had been thus sweated to the outside of the corn, and the latter had been spread out very thin, a great part of it was carried of by evaporation, insomuch that, on the ninth day, the root which was so forward on the fourth, was gone back in its vegetation, and in many instances become flaccid and brown; and it would certainly have been impracticable to carry such grain forwards to the kiln in a proper state of malting without watering it; and this accordingly was done as soon as the legal period of restriction was expired. The operation as I saw it performed was done at three separate sprinklings, turning over the corn each time, and then leaving it undisturbed from twelve to eighteen hours, according to the weather; in some cases the operation is repeated, and in others not. The water thus thrown upon the grain generally drives out a second root, not from the same aperture as the old one, but by the side of it, and this blows out the end of the corn, and makes an increase in the measure of the malt; and so very material is this considered, that the workmen, in turning the floors, tumble about the wet corn in a way purposely to beat off the old root, and in many cases I was assured they employ a besom to sweep it off.

To obtain this increase of measure is, most certainly, one of the objects of watering the floors. Before the wet corn can be brought forward to the kiln, most of the water given it on the floor must again be worked out of it, because if it is laid upon the kiln tro moist it will shrink in too much, and thereby disappoint the maltster of one of the objects which he had in view, the increase of measure in the bushel; and the circumstance of being obliged again to work the water out of the grain, keeps it several days longer from the kiln than would otherwise happen, but yet it is very far from 
being so dry and floury when brought to the kiln as the Hertfordshire malt.

The same object, that of an increase of measure, also occasions the acrospire being driven quite up to the end of the grain, and very fiequently much beyond it. The longer it is suffered to grow the more it distends the body of the corn, and of course increases the bulk of the malt. In several of the old floors which I examined I found the acrospire driven an inch out of the grain, and so uncqual was the vegetation in many of the same steepings, that the acrospire was of all lengths, from upwards of an inch out down into the body of the grain. In many foors too the corn was run together in hard bunchy knots, by the fibres of the root growing and strongly matting togetler. This originated on the water given on the floors paddling in holes, and the corn there getting a larger proportion. All this mischievous inequality of vegetation arrse entircly from the water given on the foors, and it is more or less inseparable from the practice. Nothing similar appeared on any of the Hertford:hire floors, and $I$ also observed that many of the old watered foors were mouldy, much beyond any which 1 saw in Henfordshire. It is called in the west fincry, appearing to be very common in those maltings, and it was said, by some, to be cccasioned by the floors not being watered more early. But this was rather an excuse than an explanation, for it very evidently results from the wet corn heating, and being afterwards excluded too long from the influence of the atmosphere.

Exclusive of the double root which $I$ have mentioned, and which cannot fail greatly to exhaust the corn, I paid particular attention to the quantity of root which appeared on the grain in most of the floors, and it certainly was not less than dauble the quantity which I had abserved in the Hertford-hire floors, and this I consider as one of the chief causes of the lightness and inferiority of the malt.

In the west, as in Hertfordshire, I entered into conversation with the common workmen, and endeavaured to draw from them information on the subject of their employment. Must of them maintained that watering on the floors was beneficial, 
beneficial, but when interrogated as to wherein the benefit consisted, the conclusion almost invariably was, that it was better for their masters, meaning that it produced an increase of measure. Some of thom even admitted that they knew of no other purpose it answercd, and others could only say that along with an increase it also in proved the husk of the malt, by making it brighter. There was not one, how * ever, who contended that watering made better malt for a brewer, and, almost every individual of them, allowed that it threw out more root, and on that account made light malt.

I also enquired of and waited upon sevcral of the most intelligent maltsters, to learn what they had to say upon the subject of watering. Some of them said they had made malt without watering, but that when so made, it measured less than the original barley, and the trade was this season so bad, that without an increase of measure there would be no profit; they all contended for this increase of measure, and one of the principal maltsters declared he had made good malt with an increase of two bushels in twenty, but certainly the epithet can apply to such malt in no other way than grood for sale. The same gentleman declared he was making his malt this season without watering, but the condition in which I found his corn on the foor evidently disproved this assertion. The reason he gave for not now watering was, that he made chiefly for a considerable brewer, who insisted on the grain not being watered and the brewer's reason for this was said to be, that watering so late as the tenth day made the malt finnery (moulcly), and injured the flavour of his ale. It is, however, easy to imagine that the true reason of the brewer was, that watering impoverished the mait.

The maltsters all complairnd of being greatly undersold by what is called ship malt upon the coast, and said they had heard of many sales below the value of the barley and duty, and they acknowledged that such malt was of a wretched quality (the expression was "as light as straw"); and that the injury it received in malting, and the trauds which occasimed its being sold so low, could only originate in the abuse of watering profusely on the floors. I met with 
no maltsters $* 10$ ventured to maintain, that watering on the floors inadi mall better for the brewers; but on the contrary I found brewers who were making their own malt without watering it, and precsely simblar to the Hertford. shire malt. There were also a few other houses working in the Hertfordshire way withi, $a^{*}$ watering, though the maltsters contended for the practier, hu alleged, that as they could not water su ealy as they wished, and watering so Jate as the tenth day, injured the malt, they had ieft it of altogether.

I found the mait-houses very large, roomy, and spacious, beyond any I had seen betore, and incomparably more so than the houses in Hertfordshire; but notwithstanding beir superior size, they were kept much darker and closer from the external air than the latter, and this circumstance I consider as very injudicious, and as one of the calses operating to produce their finnery or mouldy malt. several of the old foors were far mure decayed than any I met with in Hertfordshire.

In the latter place the chief object in the manufacture of malt is weight; in the west it is an increase of measure, and this was said to be from one or two bushels in twenty.

The prices of malt in Hertfordshire, were from four pounds to guineas per quarter, in the west they were said to be from seventy-four to seventy-eight shillings; it is therefore evident that the profits on their light inferior malts are at Jeast equal to those on the best made Hertfordshire malt, notwithstanding the apparent difference in the respective prices, and this withont consiciering any advantage from fraud or otherwise. It is admitted on all hands that in unwatered malt there is a loss of measure, the mait not yielding the same quantity as the barley. I alio understood that at many of the houses which I visited the frauds of short wetting bad been very extensively practised, and mumerous detectuins and proseculions had been had thereon, and it is impossible to doubt that these frauds have been and st:ll are looked up to as a source of very productive emolument, exclusivcly annexed to the watring system. In fact, notwithstanding the preference given in the market to the Hert- 
fordshire maits, they urge no complaint against that quarter, or appear to considir the malisters there as at all thurrivals; but they speak of being greatly injured bv what they call the low country and coast maltsters; and they all admit that the inferior priced malts made there can only arise from fraud and watering, admitting, certainly, that their own fratds have been suppressed while the others are stull going on. .

$\mathrm{H}_{\text {aning }}$ thus had opportunities of personally examining the two different modes of manufacturing malt, I can now speak more confidently on the practical merits of each. In Hertfordshire they are endeavouring to preserve all the substance they possibly can in the malt for the purpose of obtaining weight, whereas in the west they are purposely driving the substance ont of the grain, in order to blow up the bulk of the malt. Both objects admit of different degrees of abuse. In Hertfordshire I could observe that some of the maltsters were taking their malı too early to the kiln, and were drying it there less perfectly than it ought in both cases to promote its weight. In the west, besides wasting the corn by running out a second root, the acrospire was allowed to shoot up out of the grain, in order that it might spread over the back and increase the measure. It is also material to remark, that the lighter the malt is, the less it will press down in the bushel, and thereby measure the more. The Hertfordshire abuse has its limits, and can never extend to any mischevous length without defeating itself, but the watering abuse supports itself by the emolument rising in a nearly proportionate ratio.

$\mathrm{Qf}$ the relative values of the respective malts it would be simple to make a question; it is even decided by the very principles upon which the two parties proceed : the one labours to preserve the substance of the malt, the other purposely to dissipate it. The emolument of the former hangs on the specific gravity of the commodity, and that of the latter on its levity.

The practice of watering upon the floors, I humbly presume, has never had or can have any other object in view than that of the individual interest of the maltster, and as the sacrifice which he makes in the light and impoverished arti- 
cle which he manufactures, is a loss that falls wholly on the consumer, and he, very generally in the country', knows but little of the injury which has been done; all the advantage, without any share in the loss, rests with the manufacturer.

The numerous detections of the frauds of short wetting sufficiently establish their extent; and the great quantities of low priced malts that are still brought to market, prove that ti.ese frauds are yet in operation; and indeed, to any ore conversant with the revenue, it is easy to imagine that this mist be the case, for it is well known that excise traders, who have once shared in the large emoluments of a considerable fratu, will not, even by numernus prosecutions, be driven from the practice while they are left in possession of the same means. $I_{2}$ is on this accisunt that so many successive impr,venents are necesiary in the revenue laws; as new frauds are diveloped, new legal regulations are become expedient, to deprive the unta:r trader of his ntfarisus means; and this I humbly think is the only effectual mode of suppressing the gigantic frauds of short wetting at maithcuses.

That the present legal restriction against watering scarcely operates at all in protecion of the revenue, and but very feebly in aid of the commodity, cannot, I humbly concerve, be doubted. That material fact, that all fraululently short wet corn assumes a false age, viz. that of the prcceding steeping, as soon as it is laid upon the floor, and that the regulation of such false age is very much within the power of the maltster, fully proves that such fraudulent corn cau be timely watered under the present restriction, atmost with impunity; and the general practice of watering, which is still so much fursued, also shows that the quality of the malt is not at present within the limits of legal protection.

The former restriction of twclve days was much more effectual for both purposes, and certainly afforded all the accommodation that a fair and honourable investigation of the ease can discover to be necessary; and to sum up the whole: although that branch of the subject which includes fraud on the revenue be of itself of sufficient magnitude to demand 
strong legal interference in the process of malting, yet in my humble judgment, that most improvident waste of the commodity and mischievous injury to the community, which certainly do result from the practice of watering malt upon the floors, furnish out a case of national grievance, equally deserving the consideration of the legislature.

Excise-Office, London,

Match S, $180 \%$.

XXXV. An improved Method of making Muffles for Chemical Parposes. By Mr. Edmund Turrele*.

\section{TY MYRDS AND GENTLEMEN,}

$\mathrm{H}_{\text {AVING experienced much inconvenience in the common }}$ mode of moulding muffles on wooden blocks, for the use of chemists, enamellers, \&ic. I beg leave to lay before your praise-worthy Society, an improved method, possessing the following advantages : namely,

First, By this new method of moulding muffles, coarser and cheaper materials may be used than can be employed in the conumon mode; and which also gives them the valuable property of resisting a greater degree of heat.

Secondly, That much time will be saved hy this improved method of manufacturing them, must be allowed, when the two modes are compared.

Thirdly, The certainty of making them without cracks or flaws, and with coarser materials, will appear obvious, when it is considered, that by this improvid method, they are internally moulded instead of externally; by which means the strength of the operator may have its full effect, in firmly compressing the composition into the mould.

Whereas, in the old mode, the workman, after having spread the composition upon a cloth, guessing at its thickness, bends it over the block in the best way he can, and by thus disturbing the composition, he must needs make many.

* From Transactions of the Society for the Encouragement of Arts, Manzifactures, and Commerce, for 1807. Ten guineas were roted for this com. munication. 